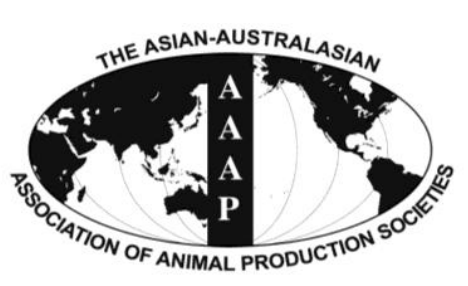

Open Access

Asian Australas. J. Anim. Sci.

Vol. 28, No. 2 : 231-238 February 2015

http://dx.doi.org/10.5713/ajas.14.0039

www.ajas.info

pISSN 1011 -2367 elSSN 1976-5517

\title{
Nutritional Value of Rice Bran Fermented by Bacillus amyloliquefaciens and Humic Substances and Its Utilization as a Feed Ingredient for Broiler Chickens
}

\author{
Supriyati*, T. Haryati, T. Susanti, and I. W. R. Susana \\ Indonesian Research Institute for Animal Production, Bogor 16720, Indonesia
}

\begin{abstract}
An experiment was conducted to increase the quality of rice bran by fermentation using Bacillus amyloliquefaciens and humic substances and its utilization as a feed ingredient for broiler chickens. The experiment was carried out in two steps. First, the fermentation process was done using a completely randomized design in factorial with 16 treatments: i) Dosage of B.amyloliquefaciens $\left(2.10^{8} \mathrm{cfu} / \mathrm{g}\right), 10$ and $20 \mathrm{~g} / \mathrm{kg}$; ii) Graded levels of humic substances, 0, 100, 200, and $400 \mathrm{ppm}$; iii) Length of fermentation, three and five days. The results showed that the fermentation significantly $(\mathrm{p}<0.05)$ reduced crude fiber content. The recommended conditions for fermentation of rice bran: $20 \mathrm{~g} / \mathrm{kg}$ dosage of inoculums B. amyloliquefaciens, $100 \mathrm{ppm}$ level of humic substances and three days fermentation period. The second step was a feeding trial to evaluate the fermented rice bran (FRB) as a feed ingredient for broiler chickens. Three hundred and seventy-five one-day-old broiler chicks were randomly assigned into five treatment diets. Arrangement of the diets as follows: $0 \%, 5 \%, 10 \%, 15 \%$, and $20 \%$ level of FRB and the diets formulation based on equal amounts of energy and protein. The results showed that $15 \%$ inclusion of FRB in the diet provided the best bodyweight gain and feed conversion ratio (FCR) values. In conclusion, the nutrient content of rice bran improved after fermentation and the utilization of FRB as a feed ingredient for broiler chickens could be included up to 15\% of the broiler diet. (Key Words: Broiler Chickens, Crude Fiber, Fermentation, Performance, Rice Bran)
\end{abstract}

\section{INTRODUCTION}

Rice bran is one of the most abundant agricultural byproducts in rice-based agricultural countries such as Indonesia and has the potential as a feed ingredient. However, its utilization especially for monogastric animals is limited. Inclusion of rice bran at more than $7.5 \%$ (normal level) in broiler ration reduced performance (Tangendjaja, 1993). The limitation of its use was due to its high fiber content, low protein and antinutritional factors such as phytic acid. The previous researchers had attempted to use different techniques, such as fermentation (Wizna et al., 2012), enzymes supplementation (Tirajoh et al., 2010) and inclusion of the fermented product (Tangendjaja, 1993; Kompiang et al., 1995) in increasing rice bran utilization for

* Corresponding Author: Supriyati. Tel: +62-251-8240752, Fax: +62-251-8240754, E-mail: skompiang@yahoo.co.id Submitted Jan. 16, 2014; Revised Mar. 10, 2014; Accepted Jun. 9, 2014 poultry feed.

In the present study, a fermentation technique was used in an attempt to improve the quality of rice bran as it is simpler and can be carried out on small farms. Bacillus amyloliquefaciens was used as the inoculum, since it had been reported to produce various enzymes such as $\alpha$ amylase, $\alpha$-acetolactate, decarboxylase, $\beta$-endoglucanase, hemicellulase, phytase, maltogenic amylase and xylanase which possess a potential to degrade fiber (Anonymous, 2012; Diaz, 2008; Wizna et al., 2007). Bacillus amyloliquefaciens effectively reduced crude fiber (CF) from tapioca by-product (Wizna et al., 2009) and rice bran (Wizna et al., 2012). Furthermore, the humic acids or substances, a class of compounds resulting from the decomposition of organic matter, particularly plants and animals in the soil, pith and lignite have been reported to stimulate the growth of micro-organisms (Huck et al., 1991). Therefore, the objective of this experiment was to improve the quality of rice bran through the fermentation technique

Copyright $@ 2015$ by Asian-Australasian Journal of Animal Sciences This is an open-access article distributed under the terms of the Creative Commons Attribution Non-Commercial License (http://creativecommons.org/licenses/by-nc/3.0/), which permits unrestricted non-commercial use, distribution, and reproduction in any medium, provided the original work is properly cited. 
using Bacillus amyloliquefaciens and humic substances, and to evaluate the feeding values this fermented rice bran (FRB) in broiler chickens.

\section{MATERIALS AND METHODS}

\section{Fermentation}

Bacillus amyloliquefaciens was obtained from the Department of Animal Feed and Nutrition, Faculty of Animal Husbandry, The University of Andalas, Padang Indonesia. It was isolated from pit soil and swampy areas by Wizna et al. (2007). The bacteria were grown on nutrient agar (Difco) and slanted at $37^{\circ} \mathrm{C}$ for $24 \mathrm{~h}$. The fully grown slants were stored at $4{ }^{\circ} \mathrm{C}$.

Inoculums were prepared as follows: fifty (50) $\mathrm{mL}$ of nutrient broth placed into a 250-mL Erlenmeyer flask was inoculated with a loop full of cells from a 24-hour-old slant and kept at $37^{\circ} \mathrm{C}$ in a rotary shaker. After $18 \mathrm{~h}$ of incubation, the culture was then absorbed in wheat flour and dried in a hot air oven at $60^{\circ} \mathrm{C}$. The dried wheat flour was then used as inoculums. By serial dilution and plating, the number of viable colonies in the inoculums was found to be $2.10^{8}$ $\mathrm{cfu} / \mathrm{g}$.

Humic substances from pith soil were extracted in sodium hydroxide and hydrochloric acid (Kompiang and Supriyati, 2007). Pith soil was added to sodium hydroxide $20 \% \mathrm{w} / \mathrm{v}$, the sedimentation and filtration separated the supernatant. The supernatant obtained was acidified with hydrochloric acid to below $\mathrm{pH} \mathrm{2,} \mathrm{and} \mathrm{a} \mathrm{black} \mathrm{precipitation}$ of humic substances occurred. Then the humic substances were separated by sedimentation and filtration, washed with acidified water $(\mathrm{pH} 2)$ and air dried at room temperature.

Solid-state fermentation was carried out as described by Supriyati and Kompiang (2002). The experiment used a completely randomized design in factorial with 16 treatments: i) Dosage of inoculums B. amyloliquefaciens $\left(2.10^{8} \mathrm{cfu} / \mathrm{g}\right), 10$ and $20 \mathrm{~g} / \mathrm{kg}$; ii) Graded level of humic substances, 0, 100, 200, and $400 \mathrm{ppm}$; iii) Length of fermentation, three and five days. Each treatment was carried out at five replicates. Crude fiber content was analyzed at the end of the fermentation period according to AOAC method (AOAC, 2005). The proximate analysis and total microbe count were done only on the lowest crude fiber content of FRB used for the feeding trial.

\section{Experimental design, animals, housing and diets}

The experimental conditions and animal procedures were handled in accordance with guidelines described by the Chicken Laboratory Program at Indonesian Research Institute for Animal Production. Three hundred and seventy-five one-day-old broiler chicks of the Arbor Acres strain were purchased from a commercial hatchery on the day of hatching and were randomly distributed into five groups, assigned to each experimental diet. Each group was subdivided into five replicates of 15 birds each. Birds were housed in an open-sided type construction of concrete and divided into pens. Each replicate was allocated to $1.50 \times 3.00$ $\mathrm{m}$ pen with a solid concrete floor covered with rice hulls and the birds were raised in a litter system. Each pen was equipped with two hanging plastic feeders and two hanging plastic waterers. Waterers were washed and water supply through waterers was changed every day. Light was provided by brooder lamps for $24 \mathrm{~h}$ per day during the first three weeks and a lighting program of $18 \mathrm{~h}$ for remaining weeks. Uniform management and vaccination schedules were followed for all birds.

The arrangement of experimental diets based on cornsoybean was as follows: $0 \%, 5 \%, 10 \%, 15 \%$, and $20 \%$ level of FRB (Table 1) and the formulation of diets based on an equal amount of energy and protein (NRC, 1994). Feeding trials were conducted for 35 days. Feed and water were given ad libitum. Birds were weighed on day 1, 21, and 35, two hours after feed withdrawal. Feed consumption and conversion ratios were measured on 21 and 35 . Mortality was recorded daily.

\section{Chemical analysis}

Ingredients and treatment diets were analyzed for dry matter, crude protein (CP), gross energy, crude fiber, crude fat, calcium and phosphorus. Dry matter was determined by drying at $135^{\circ} \mathrm{C}$ for $2 \mathrm{~h}$ (method 930.15, AOAC, 2005). Crude protein (nitrogen $\times 6.25$ ) content was determined by the micro-Kjeldahl digestion and auto analysis procedure, using auto analyzer Brand Luebe, Germany (method 990.02, AOAC, 2005). Gross energy value was determined by bomb calorimeter (Adiabatic Oxygen Bomb, Parr Instrument Co. 6400) using thermo chemical benzoic acid as a standard. Crude fiber was determined by extraction in acid and alkali solution (method 978.10, AOAC, 2005). Crude fat was determined by extraction in solvent (method 920.39, AOAC, 2005). Calcium (Ca) and phosphorus (P) contents were measured by dissolving ash sample in acids (mixture of $\mathrm{HCl}$ and $\mathrm{HNO}_{3}$ ), then calcium $(\mathrm{Ca})$ and $\mathrm{P}$ were determined by using AAS Model Varian Spectra 220 (method 942.05, AOAC, 2000) and UV-VIS Spectrophotometer (method 965.17, AOAC, 2005), respectively.

\section{Statistical analysis}

The data from the fermentation and the feeding trials were subjected to analysis of variance (Campbell, 1967) and the general linear model procedure of SAS (SAS Institute Inc., 2002), correspondingly. Differences between means were determined by Duncan's multiple range tests at significant level of $\mathrm{p}<0.05$. Orthogonal polynomial contrasts were used to examine the responses (linear and 
Table 1. Ingredients and chemical composition of diets provided during experiments

\begin{tabular}{|c|c|c|c|c|c|}
\hline \multirow{2}{*}{ Items } & \multicolumn{5}{|c|}{ Level of fermented rice bran in broiler diet $(\%)$} \\
\hline & 0 & 5 & 10 & 15 & 20 \\
\hline \multicolumn{6}{|l|}{ Ingredient (\%) } \\
\hline Fermented rice bran & 0.00 & 5.00 & 10.00 & 15.00 & 20.00 \\
\hline Soybean meal & 32.70 & 32.00 & 31.20 & 30.20 & 29.40 \\
\hline Fish meal & 8.00 & 8.00 & 8.00 & 8.00 & 8.00 \\
\hline Corn & 56.30 & 52.00 & 47.80 & 43.80 & 39.60 \\
\hline Limestone & 1.35 & 1.35 & 1.35 & 1.35 & 1.35 \\
\hline Dicalciumphosphate & 1.00 & 1.00 & 1.00 & 1.00 & 1.00 \\
\hline Salt & 0.50 & 0.50 & 0.50 & 0.50 & 0.50 \\
\hline Vitamin and mineral mix & 0.15 & 0.15 & 0.15 & 0.15 & 0.15 \\
\hline Total & 100 & 100 & 100 & 100 & 100 \\
\hline \multicolumn{6}{|l|}{ Analyzed nutrient content } \\
\hline Crude protein $(\%)$ & 22.33 & 21.52 & 21.88 & 21.69 & 22.26 \\
\hline Metabolizable energy $^{1}(\mathrm{kcal} / \mathrm{kg})$ & 3,126 & 3,143 & 3,137 & 3,096 & 3,076 \\
\hline Crude fat $(\%)$ & 5.16 & 5.31 & 5.46 & 5.51 & 5.83 \\
\hline Crude fiber $(\%)$ & 2.97 & 3.37 & 3.79 & 3.96 & 4.24 \\
\hline Calcium (\%) & 1.27 & 1.22 & 1.26 & 1.27 & 1.27 \\
\hline Phosphorus (\%) & 0.71 & 0.85 & 0.92 & 0.82 & 0.82 \\
\hline
\end{tabular}

${ }^{1}$ Metabolizable energy (ME) was calculated according to NRC (1994).

quadratic) of increasing inclusion levels of FRB in the diets (SAS Institute Inc., 2002).

\section{RESULTS}

\section{Chemical composition of fermented rice bran}

Table 2 summarizes the effects of fermentation on crude fiber content. Overall treatment had a significant $(\mathrm{p}<0.05)$ effect on the fiber content of rice bran. The levels of $B$. amyloliquefaciens added as inoculum during fermentation significantly $(\mathrm{p}<0.05)$ affected CF content. At the lower level $(10 \mathrm{~g} / \mathrm{kg})$ the $\mathrm{CF}$ content decreased from $10.62 \%$ to $8.77 \%$ or a decrease of $21.08 \%$ and at the higher level of 20 $\mathrm{g} / \mathrm{kg}$ the $\mathrm{CF}$ content decreased more sharply $(\mathrm{p}<0.05)$ to
$7.96 \%$ or a decrease of $33.40 \%$. The length of fermentation showed no significant difference $(\mathrm{p}>0.05)$ between three and five days. Crude fiber content before fermentation was $10.62 \%$ and it decreased by $21.20 \%$ after fermentation, dropping to $8.37 \%$ after three days and by $21.25 \%$ to $8.36 \%$ after five days. The addition of humic substances significantly $(\mathrm{p}<0.05)$ affected the reduction of $\mathrm{CF}$ content. The reduction of $\mathrm{CF}$ content without the addition of humic substances was $17.09 \%$ from the initial level to $8.81 \%$. This reduction was significantly $(\mathrm{p}<0.05)$ less than the reduction of $22.10 \%, 23.45 \%$, and $22.25 \%$ to $8.27 \%, 8.13 \%$, and $8.26 \%$ with the addition of humic substances of 100,200 , and $400 \mathrm{ppm}$, respectively. There was no difference between these levels of humic substances $(p>0.05)$.

Table 2. Effects of fermentation on crude fiber content (\%)

\begin{tabular}{|c|c|c|c|c|c|}
\hline \multirow{4}{*}{$\begin{array}{l}\text { Level of humic substances } \\
\text { (ppm) }\end{array}$} & \multicolumn{4}{|c|}{ Level of microbes $\left(2.10^{8} \mathrm{cfu} / \mathrm{g}\right)$} & \multirow{4}{*}{ Mean } \\
\hline & \multirow{2}{*}{\multicolumn{2}{|c|}{$\frac{10 \mathrm{~g} / \mathrm{kg}}{\text { Length of fermentation }}$}} & \multicolumn{2}{|c|}{$20 \mathrm{~g} / \mathrm{kg}$} & \\
\hline & & & \multicolumn{2}{|c|}{ Length of fermentation } & \\
\hline & Day 3 & Day 5 & Day 3 & Day 5 & \\
\hline 0 & $9.05^{\mathrm{aA}}$ & $8.93^{\mathrm{aA}}$ & $8.56^{\mathrm{bA}}$ & $8.68^{\mathrm{bA}}$ & 8.81 \\
\hline 100 & $8.72^{\mathrm{aB}}$ & $8.71^{\mathrm{aB}}$ & $7.83^{\mathrm{bB}}$ & $7.83^{\mathrm{bB}}$ & 8.27 \\
\hline 200 & $8.66^{\mathrm{aB}}$ & $8.67^{\mathrm{aB}}$ & $7.58^{\mathrm{bB}}$ & $7.61^{\mathrm{bB}}$ & 8.13 \\
\hline 400 & $8.71^{\mathrm{aB}}$ & $8.72^{\mathrm{aB}}$ & $7.84^{\mathrm{bB}}$ & $7.76^{\mathrm{bB}}$ & 8.26 \\
\hline Mean & 8.79 & 8.75 & 7.95 & 7.97 & \\
\hline
\end{tabular}

Initial crude fiber content $=10.62 \%$.

SEM, standard error mean.

${ }^{\mathrm{ab}}$ Values with different superscripts in the same row differ significantly $(\mathrm{p}<0.05)$.

${ }^{\mathrm{AB}}$ Values with different superscripts in the same column differ significantly $(\mathrm{p}<0.05)$.

Significance effects: microbes $=\mathrm{S}$, humic substances $=\mathrm{S}$, length of fermentation $=\mathrm{NS}$, microbes $\times$ humic substances $=\mathrm{S}$, microbes $\times$ length of fermentation $=\mathrm{S}$, microbes $\times$ humic substances $\times$ length of fermentation $=\mathrm{NS}(\mathrm{S}=$ significant, NS $=$ non significant at $\mathrm{p}<0.05)$. 
Table 3. Chemical composition and total microbes of rice bran before and after fermentation

\begin{tabular}{lcc}
\hline Nutrient & $\begin{array}{c}\text { Before } \\
\text { fermentation }\end{array}$ & $\begin{array}{c}\text { After } \\
\text { fermentation }\end{array}$ \\
\hline Crude protein (\%) & 12.10 & 13.40 \\
Crude fiber (\%) & 10.62 & 7.79 \\
Gross energy (kcal/kg) & 3165 & 3315 \\
Calcium (\%) & 0.08 & 0.08 \\
Phosphorus (\%) & 0.89 & 0.91 \\
Total microbes $(\mathrm{cfu} / \mathrm{g})^{1}$ & Not analysed & $2.10^{7}$ \\
\hline
\end{tabular}

${ }^{1}$ Colony forming unit/gram.

Interaction between the length of fermentation and microbial level was not significantly different $(p>0.05)$, meaning that the treatments did not influence each other. The interaction effect between the length of fermentation and humic substances supplementation was also not significant $(p>0.05)$, indicating that both treatments were not mutually influenced. There was a significant $(\mathrm{p}<0.05)$ positive interaction effect between $B$. amyloliquefaciens and humic substances levels, indicating that the effect of the addition of microbes was influenced by the addition of humic substances and vice versa. These data showed that there was a synergism between the two treatments.

Table 3 shows the nutrient composition and total microbes of the FRB in the fermentation conditions which had the lowest CF content FRB. The CP, gross energy and phosphorus contents increased after fermentation.

\section{Growth performance}

There was no disease and mortality interference recorded during the experiment. Table 4 shows the growth performances of broiler chicks fed different levels of FRB.

There was a significant difference $(\mathrm{p}<0.05)$ in feed consumption of broiler chickens between treatments and increasing inclusion levels of FRB increased (quadratic, $\mathrm{p}<0.01)$ feed consumption in the first three weeks and the remaining four to five weeks of the feeding trial. Birds fed the diets containing $20 \%$ FRB had greatest $(p<0.05)$ feed consumption among dietary treatments.

Bodyweight gain (BWG) of chicks fed experimental diets reduced linearly $(p<0.0001)$ with the increase of FRB inclusion at the levels from five to $20 \%$ during the three weeks of the feeding trial. In the finisher period, 22 to 35 days old, there were no significant $(p>0.05)$ differences among all treatments. Overall, from the age of one to 35 days, there was a significant linear decrease $(\mathrm{p}<0.01)$ in BWG with the increase of FRB inclusion. Birds fed with $20 \%$ FRB diet had the lowest BWG ( $<<0.05)$.

Furthermore, increasing inclusion levels of FRB increased (linearly, $\mathrm{p}<0.0001$ and quadratic, $\mathrm{p}<0.01$ ) feed conversion ratio (FCR) at the first three weeks of the feeding trial. From the age of 22 to 35 days, there was also a significant difference (quadratic, $\mathrm{p}<0.01$ ) in FCR among the treatments. Birds fed the diets containing 20\% FRB had greatest $(p<0.05)$ FCR value among dietary treatments. Chicks fed with $15 \%$ FRB diet had a better FCR value compared to those birds fed with other inclusion levels of FRB diets. Overall, from the age of one to 35 days, the increasing inclusion levels of FRB increased (quadratic, $\mathrm{p}<0.01)$ FCR values. The improvement of FCR values of chicks during the feeding trial fed with $15 \%$ FRB was $8.72 \%, 16.92 \%, 27.69 \%$, and $34.36 \%$ compared to those of chicks fed with $0 \%, 5 \%, 10 \%$, and $20 \%$ FRB diets, respectively. The best FCR value obtained from the birds fed the diets containing $15 \%$ FRB at the period of 22 to 35 days.

\section{DISCUSSION}

\section{The chemical composition of fermented rice bran}

The decrease of $\mathrm{CF}$ in rice bran inoculated with $B$.

Table 4. Growth performances of broiler chicks fed different levels of fermented rice bran (FRB)

\begin{tabular}{|c|c|c|c|c|c|c|c|c|}
\hline \multirow{2}{*}{ Parameter } & \multicolumn{5}{|c|}{ Level of FRB (\%) } & \multirow{2}{*}{ SEM } & \multicolumn{2}{|c|}{ FRB effects (p-value) } \\
\hline & 0 & 5 & 10 & 15 & 20 & & Linear & Quadratic \\
\hline \multicolumn{9}{|c|}{ Feed consumption (g) } \\
\hline 1 to 21 days & $913^{\mathrm{b}}$ & $964^{\mathrm{ab}}$ & $934^{\mathrm{b}}$ & $911^{\mathrm{b}}$ & $1,024^{\mathrm{a}}$ & 59.2 & NS & $*$ \\
\hline 22 to 35 days & $1,773^{\mathrm{b}}$ & $1,793^{\mathrm{b}}$ & $2,016^{\mathrm{a}}$ & $1,434^{\mathrm{c}}$ & $1,998^{\mathrm{a}}$ & 156.5 & NS & * \\
\hline 1 to 35 days & $2,687^{\mathrm{c}}$ & $2,757^{\mathrm{bc}}$ & $2,950^{\mathrm{ab}}$ & $2,345^{\mathrm{d}}$ & $3,022^{\mathrm{a}}$ & 141.7 & NS & $*$ \\
\hline \multicolumn{9}{|c|}{ Bodyweight gain (g) } \\
\hline 1 to 21 days & $474^{\mathrm{b}}$ & $504^{\mathrm{a}}$ & $471^{\mathrm{b}}$ & $453^{\mathrm{bc}}$ & $439^{c}$ & 18.3 & $* *$ & NS \\
\hline 22 to 35 days & 807 & 808 & 773 & 846 & 779 & 49.5 & NS & NS \\
\hline 1 to 35 days & $1,271^{\mathrm{ab}}$ & $1,286^{\mathrm{a}}$ & $1,187^{\mathrm{c}}$ & $1,206^{\mathrm{bc}}$ & $1,153^{\mathrm{c}}$ & 51.7 & $*$ & NS \\
\hline \multicolumn{9}{|c|}{ Feed conversion ratio } \\
\hline 1 to 21 days & $1.93^{\mathrm{b}}$ & $1.91^{\mathrm{b}}$ & $1.99^{\mathrm{b}}$ & $2.01^{\mathrm{b}}$ & $2.33^{\mathrm{a}}$ & 0.119 & $* *$ & $*$ \\
\hline 22 to 35 days & $2.20^{\mathrm{c}}$ & $2.24^{\mathrm{bc}}$ & $2.61^{\mathrm{a}}$ & $1.70^{\mathrm{d}}$ & $2.56^{\mathrm{ab}}$ & 0.174 & NS & $*$ \\
\hline 1 to 35 days & $2.12^{\mathrm{b}}$ & $2.28^{\mathrm{b}}$ & $2.49^{\mathrm{a}}$ & $1.95^{\mathrm{b}}$ & $2.62^{\mathrm{a}}$ & 0.253 & NS & $*$ \\
\hline
\end{tabular}

SEM, standard error mean, NS, non significant.

${ }^{\text {abcd }}$ Values followed by different superscripts in the same row differ significantly $(\mathrm{p}<0.05) . * \mathrm{p}<0.01, * * \mathrm{p}<0.0001$. 
amyloliquefaciens was due to the enzyme's activities during the fermentation. Wizna et al. (2009) observed a similar result of a decrease in CF contents when cassava waste was fermented with B. amyloliquefaciens. Bacillus amyloliquefaciens produces many kinds of enzymes e.g. $\alpha-$ amylase and protease (Priest et al., 1987), $\beta$-endoglucanase and $\beta$-exoglucanase (Wizna et al., 2007). These enzymes are able to transform complex molecules, particularly lignocelluloses, which are the limiting factors in animal feed, into simpler molecule components.

The recommended dosage of $20 \mathrm{~g} / \mathrm{kg} \quad B$. amyloliquefaciens as an inoculum used in this study was lower than the dosage as reported by Wizna et al. (2009) who found that the optimum level of $B$. amyloliquefaciens as an inoculum to improve the quality of cassava waste was $60 \mathrm{~g} / \mathrm{kg}$. The difference in the dosages could be due to the number of spores used and it also might be due to humic substances supplementation. Data presented in Table 2 indicated that the humic substances stimulated the growth of microbes or the production of cellulase enzymes. The mechanism of humic substances on the growth of $B$. amyloliquefaciens was not clearly known. Mirnawati et al. (2010) reported that the addition of 200 ppm humic substances to the fermentation of palm kernel cake by such microorganisms as Aspergillus niger gave an improvement of protein and a decrease of crude fiber. Huck et al. (1991) reported that humic acid stimulated the growth of microorganisms. Some hypothesized that the increase might be due to its cell wall permeability, so that the transfer of nutrients to the sphere of cell would be better, which would result in better growth. In addition, humic substances contained various minerals, both macro and micro, which were probably essential nutrients for microbes. Wizna et al. (2012) reported that the addition of mineral (zinc and sulfur) and urea in the fermentation of rice bran using cellulolytic bacteria B. amyloliquefaciens as an inoculum improved substrate characteristics and its microbial population.

Fermentation with B. amyloliquefaciens reduced $\mathrm{CF}$ content but there was no difference in the time of fermentation. From this experiment, it could not be explained why $\mathrm{CF}$ did not decrease further with the increasing fermentation period. It may have been due to a balance between the degradation and synthesis of CF in the form of microbial cell walls in the rice bran.

After fermentation, the $\mathrm{CP}$ content increased from $12.1 \%$ to $13.4 \%$. In contrast with the previous study of Supriyati and Kompiang (2002), who reported that a considerable increase in protein after the fermentation of cassava waste. This difference was most likely due to differences in the fermentation conditions, namely the addition of inorganic nitrogen sources such as urea or ammonium sulphate to the fermentation medium in the experiment of Supriyati and Kompiang (2002). In the present experiment, there was no additional nitrogen source. The increase in protein levels obtained in this experiment was likely due to decreasing in the levels of other nutrients, especially fermentable carbohydrate such that proportional protein content increased.

\section{Growth performance}

The differences in feed consumption during the first three weeks could be due to the different levels of FRB in the diets. These differences gave different levels of $\mathrm{CF}$ among all diets (Table 1), resulting in different $\mathrm{CF}$ consumption. As reported by previous studies, increasing $\mathrm{CF}$ content in the diets increased feed consumption of broiler chickens. Gonzalez-Alvarado et al. (2007) reported that the feed consumption of broiler chicks fed with diets containing different levels of $\mathrm{CF}$ (2.5\% up to $3.4 \%)$ differed significantly during the 14 to 21 days. Jimenez-Moreno et al. (2010) reported that additional $3 \%$ oat hull (4\% CF in the diet) improved feed intake in young chicks fed with low fiber diets $(2.5 \% \mathrm{CF}$ in the diet). Mateos et al. (2002) reported that the inclusion of fiber in the diet (below 5\%) might be of benefit in terms of nutrient digestibility and growth performance in broilers. The increase feed consumption in the presence of FRB in the diets compared to the control, except for treatment of $15 \%$ FRB diet, might also due to a more acceptable flavor after fermentation. In addition, fermented products were more palatable compared to the original materials as fermentation could produce preferred flavors and water soluble vitamins such as B1, B2, and B12 and minerals (Kubad et al., 1997).

The different level of FRB in the diets and the corresponding different CF content also affected the BWG in the first three weeks but did not affect the BWG in the finisher period. Gallinger et al. (2004) demonstrated that increasing the level of rice bran in diets from $10 \%$ to $20 \%$ decreased $\mathrm{BW}$ of birds at day 21 due to the increase $\mathrm{CF}$ content from $3.20 \%$ to $4.96 \%$. But the BW of broilers at day 35 was not significantly different between chicks fed with $10 \%$ and $20 \%$ rice bran diets. Gonzalez-Alvarado et al. (2008) found that the inclusion of fiber, if its content was more than $3.5 \%$ in the diet, affected the BWG of chicks during the first three weeks.

The best of FCR values in this trial were obtained with the inclusion of $15 \%$ FRB in the diets during the period of 22 to 35 days. This value was lower compared to a previous trial (Tangendjaja, 1993) who obtained a FCR value of 2.04 with Arbor Acres broiler chickens fed with a normal level of rice bran during the finisher period under Indonesian conditions. The highest FCR value in chicks fed with a $20 \%$ FRB diet might be due to its CF content, as the CF content was higher than $4 \%$ compared to other levels of FRB in the diets. Similar results were reported earlier where 
increasing the inclusion of rice bran, resulting in the increase CF contents and decreased the FCR values. Gonzalez-Alvarado et al. ( 2007) found that the inclusion of moderate amounts of fiber in low fiber diets (CF content was less than $3.5 \%$ ), improved FCR of early age chicks by reducing gizzard $\mathrm{pH}$ and improving the utilization of nutrients. Gallinger et al. (2004) reported that the inclusion of $10 \%$ rice bran in the broiler diet gave better FCR value compared to those containing $20 \%$ rice bran and control diets. Bidura et al. (2012) found that ducks fed $20 \%$ fermented rice bran using Saccharomyses cerevisiae as the inoculum had a higher FCR compared to those fed $10 \%$ fermented rice bran in their diets due to the difference of $\mathrm{CF}$ contents. Kompiang et al. (1995) reported that the inclusion of rice bran at $21 \%$ in diets supplemented with Cassapro (protein enriched cassava) provided a better FCR value compared to the control and $42 \%$ of rice bran diet.

Furthermore, the increase of the FRB in the diets increased the crude fat contents among all diets (Table 1), resulting in different crude fat consumption. These differences might affect the performances of the birds in the feeding trial. Chae et al. (2002) demonstrated that the increase of crude fat consumption depressed the birds performances. The chicks fed a diet containing defatted rice bran grew faster with increased feed intake compared to those fed diets containing fresh rice bran during the finisher period, even though there was no significant difference in growth performance during the starter period.

In Table 1, the analytical results for $\mathrm{CP}$ and metabolizable energy (ME) contents in the diets, were not equalized. These differences in contents might due to the sample uniformity and variability in measurement. The coefficient of variation $(\mathrm{CV})$ values according to Horwitz equation (AOAC International, 2012) for the CP contents was 0.95 ( $<1.3$ means acceptable) but the ME contents was 2.30 (>1.30 means not acceptable). The different of ME contents between all diets $(<70 \mathrm{kcal} / \mathrm{kg})$ would not affect the performances of broiler chickens during this feeding trial. Olomu and Offiong (1980) found that the different protein $(20 \%$ and $23 \%)$ and energy levels $(3,000$ and 3,200 $\mathrm{kcal} / \mathrm{kg}$ ) in the diets did not affect the performance of broiler chickens in the tropics.

It is difficult to explain why the highest FCR value was obtained in chicks fed with $20 \%$ FRB diet. Increasing the amount of FRB up to $20 \%$ of the diet might be attributable to antinutritional factors in the rice bran. Rice bran contains high amount of oil resulting in the growth of rancidity and some antinutritional factors, i.e. phytic acid, which depress poultry performance. Chae et al. (2002) reported that the chicks fed a diet containing defatted rice bran grew faster with increased feed intake than those fed diets containing rancid rice bran at the finisher period. However, in the present trial the feed consumption increased with increasing the inclusion levels of FRB, which indicates that an increase of rancidity in the diets did not occur. According to Tirajoh et al. (2010) that the addition of the enzyme phytase in the basal diet containing $30 \%$ of rice bran improved feed efficiency of the bird. Since the phytic acid decreased $97 \%$ during rice bran fermentation process with $B$. amyloliquefaciens as the inoculum (Wizna et al., 2012) due to the enzyme phytase activity, therefore, the effect of phytic acid would be a negligible in this feeding trial.

In term of FCR values, 15\% FRB diet was better than the other diets at 22 to 35 days. There was an improvement in FCR values $(29.41 \%)$ of chicks fed with $15 \%$ FRB compared to those of chicks fed without FRB in the diet. This FCR improvement might be also due to the presence of B. amyloliquefaciens in FRB, enhancing the availability of nutrients and making them more readily absorbable. Bacillus amyloliquefaciens produces enzymes, mainly protease and amylase, breaking down complex carbohydrates and proteins to be used as a source of energy or as structural compounds in animal reproduction. When Diaz (2008) supplemented B. amyloliquefaciens CECT 5940 at a dosage of $10^{6} \mathrm{cfu} / \mathrm{g}$ of feed to broilers, the FCR value was better than that of the control (1.84 vs 1.94). An et al. (2005) reported that FCR of groups fed with $B$. amyloliquefaciens tended to improve compared to the control group. Melegy et al. (2011) reported that Bacillus subtilis supplemented group showed a significantly better FCR compared to that of the birds in the control group. Furthermore, the FCR improvement might be due to the characteristic of humic substances. The previous researchers (Karaoglu et al., 2004; Kompiang and Supriyati, 2007) reported that the addition of humic acid to broiler chickens diet improved the FCR values. The improvement of FCR might be related to the characteristics of humic acids, such as improving gut health for better nutrient and trace element utilization and increasing digestion of protein. Another factor could be due to a growing population of non-pathogenic microbes in the gut improving the chickens' performance (Kompiang et al., 2002).

There was no mortality recorded during the experiment, indicating that the FRB containing B. amyloliquefaciens and humic substances most likely had no toxic factors. The B. amyloliquefaciens acted as a probiotic (Wizna et al., 2007; Diaz, 2008). El-Husseiny et al. (2008) reported that the immune response of the chicks fed with diets containing pro/prebiotic products was higher than those fed with diets containing natural mineral clay products as an alternative to antibiotic growth promoters. Islam et al. (2005) reviewed that humic acid had many beneficial effects as antibacterial, antiviral and anti-inflammatory in animals, improved the immune system and stress management, and reduced odor in faeces. It also had a positive effect on the liver functioning, ultimately reducing mortality and increasing 
growth in poultry.

In conclusion, the nutritional value of rice bran could be improved by fermentation using $B$. amyloliquefaciens and humic substances, with the recommended conditions being $20 \mathrm{~g} / \mathrm{kg}$ dosage of inoculums B. amyloliquefaciens $\left(2.10^{8}\right.$ $\mathrm{cfu} / \mathrm{g}), 100 \mathrm{ppm}$ level of humic substances and three days fermentation period. The utilization of FRB as a feed ingredient for broiler chickens could be included up to $15 \%$ of the broiler diet.

\section{REFERENCES}

An, B. K., B. L. Cho, S. J. You, H. D. Paik, H. I. Chang, S. W. Kim, C. W. Yun, and C. W. Kang. 2008. Growth performance and antibody response of broiler chicks fed yeast derived $\beta$ glucan and single-strain probiotics. Asian Australas. J. Anim. Sci. 21:1027-1032.

Anonymous. 2012. Benefits of Bacillus amyloliquefaciens probiotic in broilers. Norel Animal Production. Technical Bulletin No 15.

AOAC. 2000. Official Methods of Analysis. 17th edn. Association of Official Analytical Chemists, Arlington, VA, USA.

AOAC. 2005. Official Methods of Analysis. 18th edn. Association of Official Analytical Chemists, Gaithersburg, MD, USA.

AOAC International. 2012. Guidelines for Standard Method Performance Requirements. AOAC Official Methods of Analysis, 19th Ed. Appendix F, Gaithersburg, MD, USA.

Bidura, I. G. N. G., I. G. Mahardika, I. P. Suyadnya, I. B. Gaga Partama, I. G. L. Oka, D. P. M. A. Candrawati, and I. G. A. I. Aryani. 2012. The implementation of Saccharomyces spp. n-2 isolate culture (isolation from traditional yeast culture) for improving feed quality and performance of male Bali duckling. Agric. Sci. Res. J. 2:486-492.

Campbell, R. C. 1967. Statistics for Biologist. Cambridge University Press, Cambridge, UK.

Chae, B. J., K. H. Lee, and S. K. Lee. 2002. Effects of feeding rancid rice bran on growth performance and chicken meat quality in broiler chicks. Asian Australas. J. Anim. Sci. 15: 266-273.

Diaz, D. 2008. Safety and efficacy of Ecobiol ${ }^{\circledR}$ (Bacillus amyloliquefaciens) as feed additive for chickens for fattening. EFSA J. 773:2-13.

El-Husseiny, O. M, A. G. Abdallah, and K. O. Abdel-Latif. 2008. The influence of biological feed additives on broiler performance. Int. J. Poult. Sci. 7:862-871.

Gallinger, C. I., D. M. Suárez, and A. Irazusta. 2004. Effects of rice bran inclusion on performance and bone mineralization in broiler chicks. J. Appl. Poult. Res. 13:183-190.

Gonzalez-Alvarado, J. M., E. Jimenez-Moreno, R. Lazaro, and G. G. Mateos. 2007. Effect of type and cereal, heat processing of the cereal, and inclusion of fiber in the diet on productive performance and digestive traits of broilers. Poult. Sci. 86: 1705-1715.

Gonzalez-Alvarado, J. M., E. Jimenez-Moreno, D. G. Valenzia, R. Lazaro, and G. G. Mateos. 2008. Effect of fiber source and heat processing of the cereal on the development and $\mathrm{pH}$ of gastrointestinal tract of broilers fed diets based on corn or rice.
Poult. Sci. 87:1779-1795.

Huck, T. A., N. Porter, and M. E. Bushell. 1991. Effect of humates on microbial activity. Gen. Microbiol. 137:2321-2329.

Islam, K. M. S., A. Schuhmacher, and J. M. Gropp. 2005. Humic acid substances in animal agriculture. Pakistan J. Nutr. 4:126134.

Jimenez-Moreno, E., J. M. Gonzalez-Alvarado, D. GonzalezSanchez, R. Lazaro, and G. G. Mateos. 2010. Effect of type and particle size of dietary fiber on growth performance and digestive traits of broiler from 1 to 21 days of age. Poult. Sci. 89:2197-2212.

Karaoglu, M., M. Macit, N. Esenbuga, H. Durdag, L. Turgut, and O. C. Bilgin. 2004. Effect of suplemental humate at different levels on the growth performance, slaughter and carcass traits of broilers. Int. J. Poult. Sci. 3:406-410.

Kompiang, I P., A. P. Sinurat, T. Purwadaria, J. Darma, and Supriyati. 1995. Cassapro in broiler rations: Interaction with rice bran. Indonesian J. Anim. Vet. Sci. 1:86-88.

Kompiang, I P., D. Zaenuddin, and Supriyati. 2002. Effect of supplementation Bacillus apiarius or Torulaspora delbrueckii on broilers performances. Indonesian J. Anim. Vet. Sci. 7:139143.

Kompiang, I P. and Supriyati. 2007. Effect of humic acid on broilers performance. Indonesian J. Anim. Vet. Sci. 12:6-9.

Kubad, R. C., K. Singh, K. Saxena, and K. Eriksson. 1997. Microorganism as alternative source protein. Nutr. Rev. 55:6575.

Mateos, G. G., R. Lazaro, and M. I. Gracia. 2002. The feasibility of using nutritional modifications to replace drugs in poultry feeds. J. Appl. Poult. Res. 11:437-452.

Melegy, T., N. F. Khaled, R. El-Bana, and H. Abdellatif. 2011. Effect of dietary supplementation of Bacillus subtilis PB6 $\left(\right.$ Clostat $\left.^{\mathrm{TM}}\right)$ on performance, immunity, gut health ang carcass traits in broilers. J. Am. Sci. 7:891-898.

Mirnawati, Y. Rizal, Y. Marlida, and I. P. Kompiang. 2010. The role of humic acid in palm kernel cake fermented by Aspergillus niger for poultry ration. Pakistan J. Nutr. 9:182185.

National Research Council. 1994. Nutrient Requirements of Poultry. 9th Ed. National Academy Press, Washington, DC, USA.

Olomu, J. M. and S. A. Offiong. 1980. The effects of different protein and energy levels and time of change from starter to finisher ration on the performance of broiler chickens in the tropics. Poult. Sci. 59:828-835.

Priest, F. G., M. Goodfellow, L. A. Shute, and R. C. W. Berkeley. 1987. Bacillus amyloliquefaciens sp. nov., nom. rev. Int. J. Systm. Bacteriol. 37:69-71.

SAS Institute Inc. 2002. SAS/STAT User's Guide. Version 9.1. SAS Institute Inc., Cary, NC, USA.

Supriyati and I P. Kompiang. 2002. Change of nutrient composition of fermented cassava skin tubers and its utilization in broiler rations. Indonesian J. Anim. Vet. Sci. 7:150-154.

Tangendjaja, B. 1993. Effect of fermacto upon the utilization of broiler diets containing normal and high levels of rice bran. Ilmu dan Peternakan 7:16-19.

Tirajoh, S., W. G. Piliang, and P. P. Ketaren. 2010. The 
supplementation of fiber degrading enzymes and phytase in poultry diet on the performance of broiler chickens. Indonesian J. Anim. Vet. Sci. 15:40-46.

Wizna, H. Abbas, Y. Rizal, A. Dharma, and I P. Kompiang. 2007. Selection and identification of cellulase-producing bacteria isolated from the litter of mountain and swampy forest. J. Microbiol. Indonesia 1:135-139.
Wizna, H. Abbas, Y. Rizal, A. Dharma, and I. P. Kompiang. 2009. Improving the quality of tapioca by-products (onggok) as poultry feed through fermentation by Bacillus amyloliquefaciens. J. Appl. Ind. Biotechnol. Trop. Reg. 2:1-5.

Wizna, H. Abbas, Y. Rizal, A. Djulardi, and H. Muis. 2012. The effect of supplementation of micro nutrient on nutrient rice bran which fermented by Bacillus amyloliquefaciens. Pakistan J. Nutr. 11:439-443. 